\title{
Effect of prolonged in vitro exposure to high glucose on neonatal porcine pancreatic islets
}

\author{
George Harb and Gregory S Korbutt \\ Department of Surgery, Surgical-Medical Research Institute, 1074 Dentistry Pharmacy Center, University of Alberta, Alberta, Edmonton, Canada T6G 2N8 \\ (Requests for offprints should be addressed to G S Korbutt; Email: korbutt@ualberta.ca)
}

\begin{abstract}
Prolonged exposure to high glucose can influence the function, growth, and survival of pancreatic $\beta$-cells. In this study, we examine the effects of prolonged in vitro exposure to high glucose on neonatal porcine $\beta$-cells, a potentially useful source of insulin-producing cells for clinical islet transplantation. Neonatal porcine islets were prepared by culturing collagenase-digested pancreases for 1 week in $5.6 \mathrm{mM}$ glucose, followed by an additional week in either $5 \cdot 6,10 \cdot 0$, or $28.0 \mathrm{mM}$ glucose. An additional 2 days of culture in $5.6 \mathrm{mM}$ glucose followed for recovery from high glucose. The 7-day culture period in $28.0 \mathrm{mM}$ glucose failed to irreversibly impair glucose responsiveness and also caused a modest increase in $\beta$-cell mass. Immunostaining revealed that
\end{abstract}

precursor cell differentiation was responsible for the increase in $\beta$-cell mass rather than $\beta$-cell proliferation. Islet cell survival was also assessed by a DNA fragmentation assay (TUNEL stain) to determine $\beta$-cell susceptibility to apoptosis after exposure to high glucose. Interestingly, although the total number of apoptotic islet cells did not drastically change after a week of culture in either $5 \cdot 6,10 \cdot 0$, or $28 \cdot 0 \mathrm{mM}$ glucose $(25 \%$ TUNEL-positive), neither did the percentage of apoptotic $\beta$-cells. These encouraging results further support the use of neonatal porcine islets for clinical transplantation because of their ability to resist the cytotoxic effects of high glucose on islet function and survival.

Journal of Endocrinology (2006) 191, 37-44

\section{Introduction}

Pancreatic $\beta$-cells not only depend on glucose as a source of fuel, but also require it as a growth factor as well as for the regulation of glucokinase and insulin gene transcription (Liang et al. 1992, Chen et al. 1994, Gasa et al. 2000). Elevated glucose concentrations can have beneficial effects, such as stimulating $\beta$-cell growth, but also detrimental effects, such as causing impaired insulin secretion and cell death (Swenne et al. 1980, Kim et al. 2005). The adult human $\beta$-cell has been shown to be particularly susceptible to high glucose resulting in reduced glucose-stimulated insulin secretion, disproportionately elevated proinsulin secretion, and reduced islet insulin content (Eizirik et al. 1992, Ling \& Pipeleers 1996, Hostens et al. 1999, Marshak et al. 1999). In addition to impaired $\beta$-cell function, a recent study demonstrated that high glucose can cause increased $\beta$-cell death by tilting the balance of proapoptotic and antiapoptotic $\mathrm{Bcl}$ proteins towards apoptosis (Federici et al. 2001). In addition, exposure to high glucose can impair glucose signaling in $\beta$-cells by decreasing GLUT2 and glucokinase gene expression (Tsuboi et al. 2006). However, unlike adult $\beta$-cells, fetal $\beta$-cells appear less susceptible to the detrimental effects of chronic exposure to high glucose (Tuch \& Zheng 1993). Immature fetal $\beta$-cells respond poorly to glucose (Korsgren et al. 1991), whereas after birth, $\beta$-cells mature becoming glucose-responsive (Kuhl et al. 1980). Islets from neonatal animals like pigs provide an interesting model to study the effects of high glucose exposure on $\beta$-cell function and survival as well as differentiation from precursors. Neonatal porcine islets contain differentiated endocrine cells as well as their precursors which are identified by cytokeratin-7 (CK7) immunoreactivity (Trivedi et al. 2001, Rayat et al. 2003).

These islets can reverse chemically induced hyperglycemia in diabetic rodents and large animal models (Korbutt et al. 1996, Cardona et al. 2006, Kin et al. 2005). This in vivo transplantation model has been shown to be effective for recapitulating the growth and differentiation of islet cells (Lukinius \& Korsgren 2001). In the time required for this to occur, neonatal porcine islet grafts contain a suboptimal $\beta$-cell mass, which is insufficient to reverse hyperglycemia until 6-8 weeks posttransplant. During this time, the neonatal porcine islet graft is exposed to prolonged hyperglycemia, which may affect islet function, growth, and survival. The effects of high glucose exposure have not yet been studied to date, therefore in the present study neonatal porcine islets were exposed to slightly elevated $(10.0 \mathrm{mM})$ and high $(28.0 \mathrm{mM})$ glucose concentrations and assessed for $\beta$-cell function, growth, and survival in culture. 


\section{Materials and Methods}

\section{Neonatal porcine islet isolation and culture}

Islets were isolated from Landrace-Yorkshire neonatal pigs (Swine Research and Technology Center, University of Alberta) aged 1-2 days old (1.5-2.0 kg body weight) of either sex as previously described by Korbutt et al. (1996). Briefly, the pancreases were removed, cut into small pieces, and digested with $1.0 \mathrm{mg} / \mathrm{ml}$ collagenase XI (Sigma). After filtration through a nylon screen $(500 \mu \mathrm{m})$, islets were cultured for 7 days in Hams F10 medium (Gibco) containing $5.6 \mathrm{mM}$ glucose supplemented with $50 \mu \mathrm{M}$ isobutylmethylxanthine (IBMX; ICN Biomedicals, Montreal, Ontario, Canada), $0 \cdot 5 \%$ BSA (Sigma), $2 \mathrm{mM}$ L-glutamine, $10 \mathrm{mM}$ nicotinamide (BDH Biochemical, Poole, Dorset, UK), $100 \mathrm{U} / \mathrm{ml}$ penicillin, and $100 \mu \mathrm{g} / \mathrm{ml}$ streptomycin (Cambrex Bio Science, East Rutherford, New Jersey, USA) at $37^{\circ} \mathrm{C}$ in humidified $5 \% \mathrm{CO}_{2}-95 \%$ air with a change in the medium every 2 days. Following the initial week of culture in $5.6 \mathrm{mM}$ glucose, islets were divided into three groups and cultured in supplemented Hams F10 medium containing either 5•6, 10·0, or $28.0 \mathrm{mM}$ glucose for an additional 7 days with a change in the medium every 2 days. Islets from each group were then returned to $5 \cdot 6 \mathrm{mM}$ glucose for an additional 2 days.

\section{Cellular insulin and DNA content analysis}

Determination of cellular insulin content was accomplished by measuring duplicate samples by RIA (Diagnostic Products Corp., Los Angeles, CA, USA). Samples were sonicated in $2 \mathrm{mM}$ acetic acid containing $0 \cdot 25 \%$ BSA, centrifuged $(800 \mathrm{~g}$, $15 \mathrm{~min}$ ), and the supernatants were collected and stored at $-20{ }^{\circ} \mathrm{C}$ until the time of assay. The DNA content was analyzed using PicoGreen, an ultra-sensitive fluorescent nucleic acid stain for double-stranded DNA (Molecular Probes, Eugene, OR, USA), according to the manufacturer's instructions. Duplicate aliquots were washed in citrate buffer $(150 \mathrm{mM} \mathrm{NaCl}, 15 \mathrm{mM}$ citrate, $3 \mathrm{mM}$ EDTA, $\mathrm{pH} 7 \cdot 4$ ) and stored as cell pellets at $-20^{\circ} \mathrm{C}$. Cell pellets were resuspended in lysis buffer $(10 \mathrm{mM}$ Tris, $1 \mathrm{mM}$ EDTA, $0 \cdot 5 \%$ Triton $\left.\mathrm{X}-100,4{ }^{\circ} \mathrm{C}, \mathrm{pH} 7 \cdot 5\right)$, sonicated, and then analyzed (Korbutt et al. 1996).

\section{Glucose-stimulated insulin secretion}

Islet insulin secretory activity in response to an in vitro stimulatory glucose challenge was assessed using a static incubation assay (Korbutt et al. 1996). Islets were washed twice with Hams F10 medium containing $0 \cdot 5 \%$ BSA and $2 \cdot 8 \mathrm{mM}$ glucose, and samples were taken for determination of cellular insulin content. Islets were cultured in 24-well plates and incubated in $1.5 \mathrm{ml}$ of Hams F10 medium supplemented with $0.5 \%$ BSA and either 2.8 or $20.0 \mathrm{mM}$ glucose for $120 \mathrm{~min}$. At the end of the incubation, supernatants were collected for measurement of insulin release by RIA. Insulin secretion was calculated by dividing the insulin released into the supernatant by the cellular insulin content of the islets (percent of content). Stimulation indices were calculated by dividing the percentage of insulin released at $20.0 \mathrm{mM}$ glucose by that released at $2.8 \mathrm{mM}$ glucose. Insulin release per $\beta$-cell was calculated by dividing the amount of insulin released into the culture medium by the number of $\beta$-cells. Based on the determination of total islet cellular DNA content and the percentage of insulin-positive cells, the following equation was used to calculate the total number of $\beta$-cells (Korbutt et al. 1996):

$\frac{\text { Total DNA content }}{7 \cdot 1 \mathrm{pg} \text { DNA/cell }}$
$\times \frac{\% \text { Insulin-positive cells }}{100}=$ number of $\beta$-cells

\section{Differentiation, proliferation, and apoptosis}

To determine the percentage of insulin-positive $\beta$-cells, CK7positive ductal epithelial cells, and proliferating cells, islets were dissociated into single cell suspensions to facilitate quantification of stained cells (Korbutt et al. 1996). Islets were dissociated by mechanical disruption using siliconized glass pipettes at $37^{\circ} \mathrm{C}$ in calcium-free HBSS medium supplemented with $1 \mathrm{mM}$ EGTA and $0.5 \%$ BSA for $7 \mathrm{~min}$ before addition of trypsin $(25 \mu \mathrm{g} / \mathrm{ml}$; Boehringer Mannheim, Laval, Canada) and DNAse $(4 \mu \mathrm{g} / \mathrm{ml}$, Boehringer), and further pipetting for $10 \mathrm{~min}$. Cells were washed, resuspended in PBS, and allowed to adhere onto Histobond microscope slides (Paul Marienfeld GmbH \& Co. KG, Lauda-Koenigshofen, Germany) before fixation in Bouin's fixative for $12 \mathrm{~min}$. Microwave antigen retrieval for CK7 staining was performed for $1.5 \mathrm{~min}$ in $50 \mathrm{ml}$ of target retrieval solution, $\mathrm{pH} 9$ (S2368, Dako, Mississauga, Canada). Blocking was performed with 20\% normal goat serum (Fischer Scientific, Edmonton, AB, Canada) for $30 \mathrm{~min}$. Primary antibodies were purchased from Dako and used at the following concentrations: 1:1000 guinea pig anti-porcine insulin, 1:25 mouse anti-human CK7, and 1:100 mouse anti-rat proliferating cell nuclear antigen (PCNA) for $1 \mathrm{~h}$ at room temperature in a humidified chamber followed by two washes in PBS before addition of the secondary antibody. Secondary antibodies were as follows: fluorescein isothiocyanate (FITC)-conjugated goat antiguinea pig and Cy3-conjugated donkey anti-mouse, both purchased from Jackson Immunoresearch Laboratories, Inc. (West Grove, PA, USA) and used at a dilution of 1:200 for $1 \mathrm{~h}$. Double staining for insulin and PCNA was performed in sequential order of primary followed by secondary antibodies. The percentage of PCNA-positive islet cells was calculated by dividing the number of PCNA-positive cells by the total number of cells. The percentage of proliferating $\beta$-cells was determined by dividing the number of PCNA and insulin double positive cells by the total number of insulin-positive cells. Apoptotic cells were detected by TUNEL staining (Promega) according to the manufacturer's instructions on intact islets fixed in $4 \%$ paraformaldehyde for $30 \mathrm{~min}$, then 
embedded in a $2 \%$ low-melting point agarose solution and allowed to harden at $4{ }^{\circ} \mathrm{C}$ before processing, paraffin embedding, and sectioning $(5 \mu \mathrm{m})$. Sections of islets were stained for apoptotic cells and counterstained for insulin. Slides were coverslipped with Vectashield (Vector) and viewed using a Zeiss Axioskop II fluorescent microscope with a Coolsnap camera. The percentage of TUNEL-positive cells was determined by dividing the number of TUNEL-positive cells by the total number of cells. The percentage of apoptotic $\beta$-cells was determined by dividing the number of TUNEL and insulin double positive cells by the total number of insulin-positive cells. Cell counts were performed on a minimum of 500 cells per sample and percentages were calculated as the number of positive cells per 500 .

\section{Statistical analysis}

Results are presented as mean \pm s.E.M. of three independent experiments performed with islets prepared from at least three pancreases. Statistical comparisons were performed using the one-way ANOVA test with SPSS statistical software, version 12.0 for Windows (Chicago, IL, USA). A $P$ value of $<0.05$ was considered significant.

\section{Results}

Effect of high glucose on neonatal porcine islet recovery and insulin secretory activity

Immediately after collagenase digestion of neonatal porcine pancreases, digested tissue was cultured in Hams F10 medium containing $5.6 \mathrm{mM}$ glucose for 1 week. The resultant islets were then switched to media containing either $5 \cdot 6,10 \cdot 0$, or $28.0 \mathrm{mM}$ glucose for an additional week to compare the effects of prolonged exposure to high glucose on islet recovery and insulin secretory activity. Islets cultured in high glucose $(28.0 \mathrm{mM})$ contained the least amount of recoverable cellular insulin after 1 week of culture $(42 \cdot 0 \pm 4 \cdot 7 \%)$, although a week of culture in 5.6 and $10.0 \mathrm{mM}$ glucose also significantly reduced cellular insulin content $(63 \cdot 2 \pm 6 \cdot 4$ and $55 \cdot 8 \pm 3 \cdot 8 \%$ respectively; Table 1). Similarly, $\beta$-cell insulin content decreased dramatically following a week of culture in $28.0 \mathrm{mM}$ glucose compared with 5.6 or $10.0 \mathrm{mM}$ glucose $(P<0.05$; Table 1$)$. The decrease in insulin content after incubation at $28.0 \mathrm{mM}$ glucose was accompanied by increased cellular DNA recovery compared with islets cultured at 5.6 or $10.0 \mathrm{mM}$ glucose $(P<0.05$; Table 1$)$. After a week of culture at different glucose concentrations, islets from each group were returned to physiological glucose $(5.6 \mathrm{mM})$ for two additional days of culture. During these 2 days, islet cellular insulin content was partially restored as both the total amount of recoverable islet and individual $\beta$-cell insulin contents increased (Table 1).

To evaluate the insulin secretory activity of islets after culture at different glucose concentrations, we compared the
Table 1 Recovery of cellular insulin and DNA content as well as $\beta$ cell insulin content after culture at different glucose concentrations

\begin{tabular}{|c|c|c|c|c|}
\hline & \multirow[t]{2}{*}{$\begin{array}{l}\text { Medium } \\
\text { glucose }(\mathrm{mM})\end{array}$} & \multicolumn{2}{|l|}{$\%$ Recovery } & \multirow[t]{2}{*}{$\begin{array}{l}\text { Insulin content } \\
\text { (pg per } \beta \text {-cell) }\end{array}$} \\
\hline & & Insulin & DNA & \\
\hline Week 1 & $5 \cdot 6$ & $100 \cdot 0^{\mathrm{a}}$ & $100 \cdot 0^{\mathrm{b}}$ & $14 \cdot 3 \pm 1 \cdot 6$ \\
\hline \multirow[t]{3}{*}{ Week 2} & $5 \cdot 6$ & $63 \cdot 2 \pm 6 \cdot 4$ & $82 \cdot 8 \pm 4 \cdot 1$ & $9 \cdot 9 \pm 1 \cdot 5$ \\
\hline & $10 \cdot 0$ & $55 \cdot 8 \pm 3 \cdot 8$ & $73 \cdot 0 \pm 2 \cdot 1$ & $9 \cdot 1 \pm 2 \cdot 1$ \\
\hline & $28 \cdot 0$ & $42 \cdot 0 \pm 4 \cdot 7$ & $104 \cdot 8 \pm 3 \cdot 2^{c}$ & $3 \cdot 7 \pm 0 \cdot 7^{\mathrm{d}}$ \\
\hline 2 Day & $5 \cdot 6-5 \cdot 6$ & $59 \cdot 5 \pm 5 \cdot 4$ & $77 \cdot 7 \pm 1 \cdot 6$ & $10 \cdot 2 \pm 2 \cdot 2$ \\
\hline \multirow[t]{2}{*}{ Recovery } & $10 \cdot 0-5 \cdot 6$ & $62 \cdot 2 \pm 4 \cdot 4$ & $78 \cdot 0 \pm 0 \cdot 7$ & $10 \cdot 3 \pm 1 \cdot 9$ \\
\hline & $28 \cdot 0-5 \cdot 6$ & $68 \cdot 4 \pm 9 \cdot 5$ & $80 \cdot 1 \pm 1 \cdot 9$ & $7 \cdot 2 \pm 2 \cdot 0$ \\
\hline
\end{tabular}

Cellular insulin $(5065 \cdot 9 \pm 670 \cdot 0 \mathrm{ng})$ and DNA $(12 \cdot 5 \pm 0 \cdot 2 \mu \mathrm{g})$ content values are expressed as recoveries of week 1 values arbitrarily set at $100 \cdot 0 \%$. Insulin content was calculated by dividing the total insulin content of islets by the number of $\beta$-cells $(n=3)$. ${ }^{a} P<0.05$ versus week 2 and 2 days recovery values. ${ }^{\mathrm{b}} P<0 \cdot 05$ versus week $2-5.6$ and $10.0 \mathrm{mM}$ and 2 days recovery values. ${ }^{\mathrm{c}} P<0.05$ versus week 1,2 and 2 days recovery values. ${ }^{\mathrm{d}} P<0.05$ versus week 1,2 and 2 days recovery. Data are mean \pm s.E.M.

percentage of insulin released by islets after stimulation with low $(2 \cdot 8 \mathrm{mM})$ or high $(20 \cdot 0 \mathrm{mM})$ glucose. Following the first week of culture in $5.6 \mathrm{mM}$ glucose, islets exhibited a stimulation index of $3 \cdot 9 \pm 0 \cdot 1$ in response to a $20.0 \mathrm{mM}$ glucose challenge (Table 2 ). The insulin released per $\beta$-cell in response to a high glucose challenge was $5 \cdot 5 \pm 0 \cdot 7 \times 10^{-4} \mathrm{ng}$, or $4 \cdot 0 \pm 0 \cdot 2 \%$ of the total intracellular insulin stores. After exposing islets to $10 \cdot 0 \mathrm{mM}$ glucose for 1 week, the insulin secretory response to $20 \cdot 0 \mathrm{mM}$ glucose $(9 \cdot 4 \pm 0 \cdot 2 \%$ insulin release) was significantly higher compared with islets cultured at $5 \cdot 6$ or $28.0 \mathrm{mM}$ glucose for 1 week $(6 \cdot 2 \pm 0 \cdot 3 \%$ vs $7 \cdot 7 \pm$ $0 \cdot 2 \%$ respectively; $P<0 \cdot 05$; Table 2 ). However, the stimulation indices of islets were similar after culture at 5.6 and $10 \cdot 0 \mathrm{mM}$ glucose $(3 \cdot 4 \pm 0 \cdot 4$ vs $3 \cdot 9 \pm 0 \cdot 0$ respectively), despite a non-statistically significant higher basal insulin release after culture in $10 \cdot 0 \mathrm{mM}$ glucose $(1 \cdot 8 \pm 0 \cdot 1$ and $2 \cdot 4 \pm 0 \cdot 1 \%$ respectively; Table 2). Culture in $28.0 \mathrm{mM}$ glucose for 1 week caused significantly increased basal insulin secretion $(3 \cdot 0 \pm 0 \cdot 3 \%)$, while only slightly reducing stimulated insulin release in response to $20 \cdot 0 \mathrm{mM}$ glucose $(7 \cdot 7 \pm 0 \cdot 2 \%, P<0 \cdot 05$, Table 2), resulting in a significantly reduced $(P<0 \cdot 05)$ stimulation index $(2 \cdot 6 \pm 0 \cdot 2)$ compared with islets cultured at $5 \cdot 6$ and $10 \cdot 0 \mathrm{mM}$ glucose.

Despite there being no change in $\beta$-cell insulin content after culture in either 5.6 or $10.0 \mathrm{mM}$ glucose $(9.9 \pm 1.5$ and $9 \cdot 1 \pm 2 \cdot 1 \mathrm{pg}$ respectively), islets cultured in $10 \cdot 0 \mathrm{mM}$ glucose were more responsive to a glucose challenge and hence released more insulin compared with those cultured at $5 \cdot 6 \mathrm{mM}\left(9 \cdot 2 \pm 1 \cdot 7\right.$ vs $4 \cdot 3 \pm 0 \cdot 2 \times 10^{-4} \mathrm{ng}$ respectively; $P<0.05$; Table 2). Islets, which were cultured in $28.0 \mathrm{mM}$ glucose, contained the least cellular insulin content $(3 \cdot 7 \pm$ $0.7 \mathrm{pg} / \beta$-cell), and thus released even less insulin $(2 \cdot 5 \pm 0 \cdot 6 \times$ $10^{-4} \mathrm{ng}$ ) upon glucose stimulation.

Stimulation indices of islet from all groups were restored to similar values after the 2-day recovery period $(5.6 \mathrm{mM}$ glucose) compared with before, but were also lower due to 
Table 2 Glucose-stimulated insulin release after culture at different glucose concentrations

\begin{tabular}{|c|c|c|c|c|c|c|}
\hline & \multirow[t]{2}{*}{ Medium glucose (mM) } & \multicolumn{2}{|c|}{ Insulin secretory activity (\% content) } & \multicolumn{2}{|c|}{ Insulin release $/ \boldsymbol{\beta}$-cell $\left(\times 10^{-4} \mathrm{ng}\right)$} & \multirow[t]{2}{*}{ Stimulation index } \\
\hline & & $2 \cdot 8 \mathrm{mM}$ & $20 \cdot 0 \mathrm{mM}$ & $2 \cdot 8 \mathrm{mM}$ & $20 \cdot 0 \mathrm{mM}$ & \\
\hline Week 1 & $5 \cdot 6$ & $1 \cdot 0 \pm 0 \cdot 2^{\mathrm{a}}$ & $4 \cdot 0 \pm 0 \cdot 2$ & $1 \cdot 7 \pm 0 \cdot 1$ & $5 \cdot 5 \pm 0 \cdot 7$ & $3 \cdot 9 \pm 0 \cdot 1^{\mathrm{e}}$ \\
\hline \multirow{2}{*}{ Week 2} & $10 \cdot 0$ & $2 \cdot 4 \pm 0 \cdot 1$ & $9 \cdot 4 \pm 0 \cdot 2^{b}$ & $2 \cdot 4 \pm 0 \cdot 1$ & $9 \cdot 2 \pm 1 \cdot 7^{d}$ & $3 \cdot 9 \pm 0 \cdot 0^{g}$ \\
\hline & $28 \cdot 0$ & $3 \cdot 0 \pm 0 \cdot 3$ & $7 \cdot 7 \pm 0 \cdot 2^{c}$ & $1 \cdot 0 \pm 0 \cdot 1$ & $2 \cdot 5 \pm 0 \cdot 6$ & $2 \cdot 6 \pm 0 \cdot 2$ \\
\hline 2 Day & $5 \cdot 6-5 \cdot 6$ & $2 \cdot 6 \pm 0 \cdot 2$ & $4 \cdot 2 \pm 0 \cdot 1$ & $2 \cdot 9 \pm 0 \cdot 3$ & $4 \cdot 9 \pm 0 \cdot 8$ & $1 \cdot 6 \pm 0 \cdot 1$ \\
\hline
\end{tabular}

A $120 \mathrm{~min}$ in vitro static glucose-stimulated insulin release assay was conducted after culture at different glucose concentrations. The stimulation indices were calculated by dividing the amount of insulin released at high glucose $(20 \cdot 0 \mathrm{mM})$ by that released at low glucose $(2 \cdot 8 \mathrm{mM} ; n=3) .{ }^{\text {a }} P<0 \cdot 05 \mathrm{vs} 28 \cdot 0,28 \cdot 0-5 \cdot 6 \mathrm{mM}$. ${ }^{\mathrm{b}} P<0 \cdot 05$ versus all except $28 \cdot 0 \mathrm{mM} .{ }^{\mathrm{c}} P<0 \cdot 05$ versus all except $5 \cdot 6,10 \cdot 0 \mathrm{mM}$. ${ }^{\mathrm{d}} P<0 \cdot 05 \mathrm{vs} 5 \cdot 6,28 \cdot 0,10 \cdot 0-5 \cdot 6,28 \cdot 0-5 \cdot 6 \mathrm{mM}$. ${ }^{\mathrm{e}, \mathrm{f}, \mathrm{g}} P<0 \cdot 05 \mathrm{vs} 28 \cdot 0,5 \cdot 6-5 \cdot 6$, $10 \cdot 0-5 \cdot 6,28 \cdot 0-5 \cdot 6 \mathrm{mM}$. Data are mean \pm S.E.M.

increased basal insulin release as well as reduced stimulated insulin release (Table 2).

\section{Effect of high glucose on neonatal porcine $\beta$-cell differentiation, proliferation, and apoptosis}

The porcine $\beta$-cell mass is dynamic and can increase by both precursor differentiation and $\beta$-cell replication (Trivedi et al. 2001, Bock et al. 2003). To examine the effect of high glucose on $\beta$-cell differentiation, we assessed the proportion of CK7-positive ductal epithelial cells in islets exposed to different glucose concentrations in vitro. Islets contained 30-35\% CK7-positive cells after 7 days of culture in either 5.6 or $10.0 \mathrm{mM}$ glucose. This percentage was reduced to $18 \cdot 8 \pm 1 \cdot 7 \%$ after culture in $28 \cdot 0 \mathrm{mM}$ glucose, while the percentage of $\beta$-cells increased to $29 \cdot 3 \pm 0 \cdot 6 \%$ (Fig. 1).

Neonatal porcine islet cell proliferation has been shown to occur both in vitro (Nielsen et al. 2003) and in vivo (Trivedi et al. 2001), and was assessed here after exposure to different glucose concentrations for 7 days. To determine the percentage of proliferating $\beta$-cells, dispersed neonatal porcine islet cells were immunostained for both insulin and PCNA. PCNA protein expression is strictly correlated to cell proliferation and the active phases of the cell cycle (Maga \& Hubscher 2003). The number of PCNA-positive cells (30\%) was similar to the number of Ki-67-positive cells (25\%) reported in neonatal porcine islets after 7 days culture in $10 \mathrm{mM}$ glucose (Nielsen et al. 2003). By day 14 of culture in $5.6 \mathrm{mM}$ glucose, the percentage of both the total population of PCNA-positive islet cells and PCNA-positive $\beta$-cells had dropped significantly by $32 \cdot 3 \pm 3 \cdot 7$ and $53 \cdot 3 \pm 7 \cdot 4 \%$ respectively $(P<0.05$; Fig. 1b). Culture in 10.0 and $28.0 \mathrm{mM}$ glucose did little to affect the percentage of proliferating islet and $\beta$-cells significantly compared with $5.6 \mathrm{mM}$ glucose (Fig. 1b).

Next, neonatal porcine islet cell apoptosis was examined using the TUNEL method to identify DNA fragmentation (Fig. 2). Islet cell apoptosis was assessed in intact islets embedded in agarose using the TUNEL method and co-stained for insulin to identify apoptotic $\beta$-cells. Repre- sentative islets examined after 14 days culture in $5.6 \mathrm{mM}$ glucose showed extensive TUNEL labeling (Fig. 2a). Only few of the islet cells undergoing apoptosis are insulin-positive (Fig. $2 \mathrm{~b}$ and c). Both whole islet and $\beta$-cell apoptosis were not significantly increased after exposure to high glucose concentrations $(28.0 \mathrm{mM}), 1$ week in culture (Fig. $2 \mathrm{~d}$ ).

\section{Discussion}

The data obtained in the present study suggest that neonatal porcine islets exposed to high glucose concentrations in vitro leads to a proportional increase in $\beta$-cells, with only a moderate effect on $\beta$-cell function and survival. Exposure to elevated glucose concentrations in culture decreased the insulin content of neonatal porcine islets in a way similar to that described for fetal porcine and adult human islets in tissue culture (Korsgren et al. 1989, Marshak et al. 1999). In addition to the observed $\beta$-cell degranulation, function was also modified by prolonged in vitro exposure to different glucose concentrations. Islets cultured in $10.0 \mathrm{mM}$ glucose exhibited higher insulin secretion when compared with those exposed to either $5 \cdot 6$ or $28.0 \mathrm{mM}$ glucose. However, in these islets, the insulin secretion in response to $2.8 \mathrm{mM}$ glucose was also increased resulting in a stimulation index comparable with that for islets cultured in $5.6 \mathrm{mM}$ glucose. Exposure to $28.0 \mathrm{mM}$ glucose also increased basal insulin release and reduced stimulated insulin release at $20.0 \mathrm{mM}$ glucose, thereby resulting in a significantly decreased stimulation index.

Restoration of the glucose concentration to normal $(5.6 \mathrm{mM})$ for 2 days, restored the stimulation index to levels similar to those for islets which had been previously cultured in 5.6 and $10.0 \mathrm{mM}$ glucose, suggesting the detrimental effects of high glucose are reversible. One reason for this may be the increased insulin biosynthesis which occurs in $\beta$-cells that are allowed to recover in $5.6 \mathrm{mM}$ glucose following chronic stimulation for 1 week in $28.0 \mathrm{mM}$ glucose. Increased insulin biosynthesis after culture at $5.6 \mathrm{mM}$ glucose could account for the greater insulin content and release per cell seen after the recovery period. 

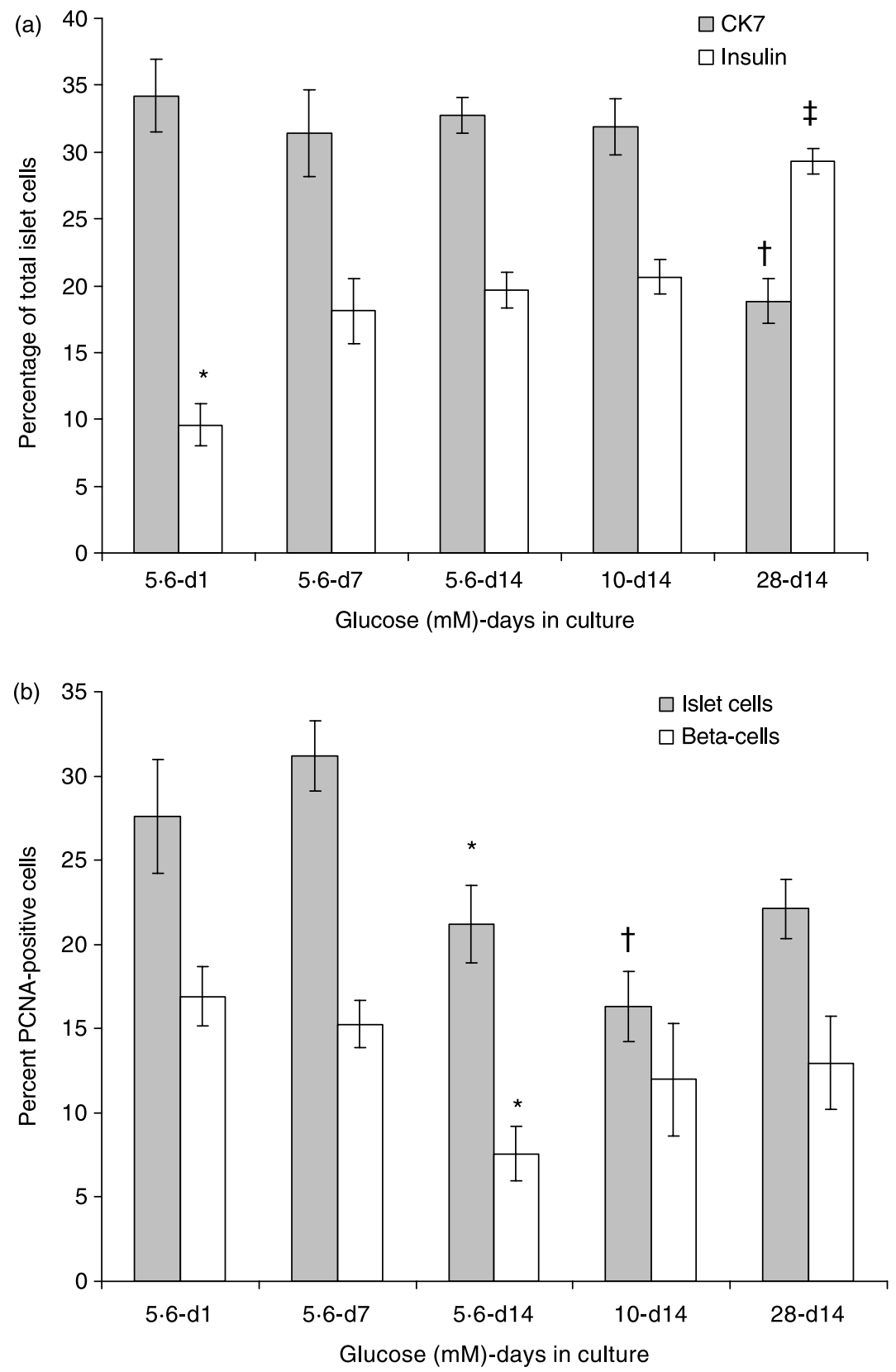

Figure 1 Effect of high glucose culture on neonatal porcine $\beta$-cell differentiation and proliferation. (a) Neonatal porcine islets were cultured in $5.6 \mathrm{mM}$ glucose for 7 days and then switched to either 10.0 or $28.0 \mathrm{mM}$ glucose for an additional 7 days. The percentage of $\beta$-cells in islets cultured for 7 days in $28.0 \mathrm{mM}$ glucose had significantly increased, while the percentage of CK7-positive cells decreased $(n=3)$. ${ }^{*} P<0 \cdot 05$ vs insulin-positive cells cultured in $5 \cdot 6-\mathrm{d} 7-\mathrm{d} 14,10-\mathrm{d} 14,28-\mathrm{d} 14 .{ }^{\dagger} P<0 \cdot 05$ vs CK7-positive cells cultured in $5 \cdot 6$ $\mathrm{d} 1, \mathrm{~d} 7, \mathrm{~d} 14,10-\mathrm{d} 14 .{ }^{\ddagger} P<0 \cdot 05$ vs insulin-positive cells cultured in $5 \cdot 6-\mathrm{d} 1, \mathrm{~d} 7, \mathrm{~d} 14,10-\mathrm{d} 14$. (b) Proliferating islet cells and $\beta$-cells decreased at the end of 2 weeks in culture in $5.6 \mathrm{mM}$ glucose. High glucose culture had no effect on the percentage of proliferating cells $(n=3)$. ${ }^{*} P<0.05$ vs proliferating islet ( $\beta$ and non- $\beta$-cells) and $\beta$-cells after culture in $5.6 \mathrm{mM}$ glucose for 1 and 7 days. ${ }^{+} P<0.05$ vs proliferating islet cells after culture in $5.6 \mathrm{mM}$ glucose for 1 and 7 days. 

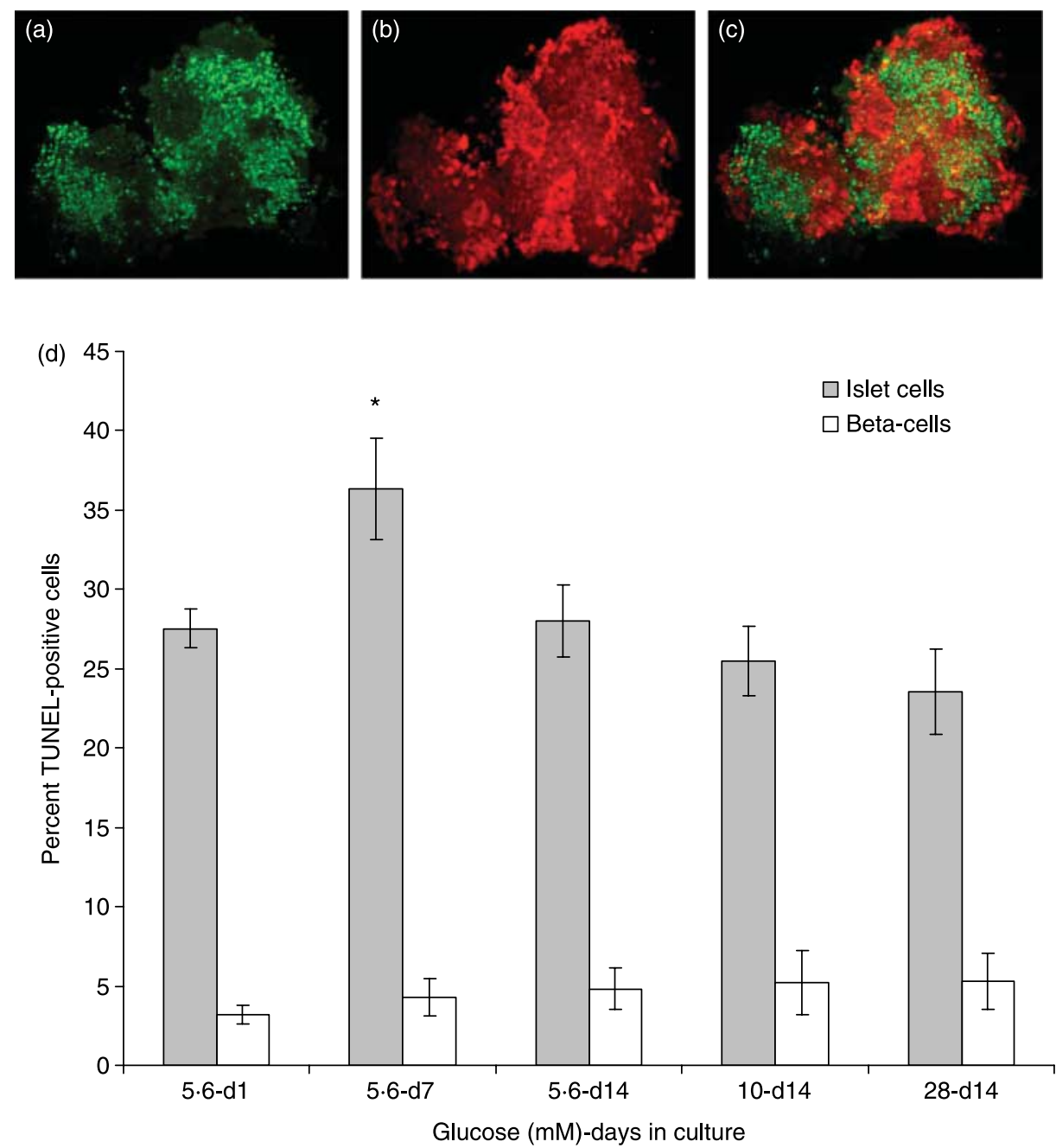

Figure 2 Effect of high glucose culture on neonatal porcine $\beta$-cell apoptosis. (a-c) Representative islets cultured for 14 days in $5.6 \mathrm{mM}$ glucose were examined for apoptosis using a fluorescent DNA fragmentation assay (TUNEL stain). Microscopic fields of islets were photographed individually to detect apoptotic cells (a) and $\beta$-cells (b) and merged to detect apoptotic $\beta$-cells (c). Magnification, $\times 200$.

It is also noteworthy that the high glucose exposure in the present study induced more severe impairments in adult human $\beta$-cell function (Eizirik et al. 1992) than what has been observed for neonatal porcine $\beta$-cells in this study. One possible reason to explain this difference may be due to the presence of nicotinamide used in the neonatal islet culture medium. Nicotinamide has been shown to protect against the cytotoxic action of streptozotocin on $\beta$-cells as well as significantly increase glucose-stimulated insulin secretion (Sandler et al. 1983, Korbutt et al. 1996). When cultured with nicotinamide, neonatal porcine islets have been shown to be protected from $\beta$-cell desensitization following prolonged exposure to high glucose (Ohgawara et al. 1993). The use of nicotinamide in culture media in this study may explain why islets cultured at $28.0 \mathrm{mM}$ glucose still managed to respond with increased insulin release in response to a $20 \cdot 0 \mathrm{mM}$ glucose stimulation. The Hams F10 medium used in this study contains niacin, a derivative of nicotinamide, and is also supplemented with additional nicotinamide to a final concentration of $10 \cdot 0 \mathrm{mM}$. In many of the studies examining the effects of high glucose concentrations on adult human islets, media was used which either contained no (Eizirik et al. 1992, Hostens et al. 1999, Marshak et al. 1999, Federici et al. 2001) or very little (2.0 mM) nicotinamide (Ling \& Pipeleers 1996).

High glucose concentrations in culture can influence precursor cell differentiation into $\beta$-cells with only a minimal effect on cell replication and apoptosis. In vivo evidence in support of the role of hyperglycemia on precursor cell differentiation was reported by Yoon et al. (1999). Their group as well as ours (unpublished observation) have noticed a greater tendency for neonatal porcine islet grafts to develop a 
more substantial $\beta$-cell mass when implanted into diabetic (hyperglycemic) animals compared with non-diabetic (normoglycemic) recipients (Yoon et al. 1999). Recent studies have shown that adult stem cells cultured in high glucose medium are able to transdifferentiate into insulin-producing cells (Yang et al. 2002, Cao et al. 2004, Tang et al. 2004). The ability of islets in postnatal life to respond to hyperglycemia by increased precursor cell differentiation has previously been reported to occur in vivo (Bonner-Weir et al. 1989).

In addition to precursor differentiation, replication of preexisting $\beta$-cells has been reported to contribute to the increased $\beta$-cell mass seen in transplanted neonatal porcine islet grafts (Trivedi et al. 2001). The lack of an effect of high glucose on islet cell replication contradicts the results of King \& Chick (1976) who found that elevated glucose concentrations $(16 \cdot 5-27.5 \mathrm{mM})$ increased the frequency of replicating neonatal rat $\beta$-cells in culture. However, one study reported that high glucose $(28 \mathrm{mM})$ was ineffective and may even inhibit $\beta$-cell proliferation in islets from 3-day-old neonatal rats (Kaung 1983). Taken together, these results may suggest that the effects of high glucose on $\beta$-cell proliferation and differentiation are species-dependent.

Quite possibly, the most significant result of this study is the demonstration that high glucose does not significantly increase the percentage of apoptotic cells in neonatal porcine islets. Unlike adult human islets which contain $48 \%$ apoptotic $\beta$-cells after exposure to $16.7 \mathrm{mM}$ glucose for 5 days (Federici et al. 2001), neonatal porcine islets contained $<5 \%$ apoptotic $\beta$-cells even after exposure to $28.0 \mathrm{mM}$ glucose for 7 days. Despite the low number of apoptotic $\beta$-cells, the percentage of total islet cells undergoing apoptosis was approximately 30\%, which has also been reported by others (Yoon et al. 1999). This high percentage of cell death, which is present even at the beginning of the culture period (day 1), has been attributed to the isolation procedure since $30 \%$ of islet cells have been reported to be undergoing apoptosis immediately following the isolation and culture of both human and porcine pancreases (Paraskevas et al. 2000, Stadlbauer et al. 2003). The ability of the neonatal porcine islet cells to resist the toxic effects of high glucose is of paramount importance for their ability to survive posttransplantation. Sustained exposure to hyperglycemia in the posttransplant environment can contribute to increased $\beta$-cell apoptosis and reduced $\beta$-cell mass (Biarnes et al. 2002). While many of these studies were performed using adult islets, donor age can significantly affect cell survival. Neonatal islets are known to be more robust and to survive better in tissue culture compared with fragile adult islets. This robustness may be due to the metabolic immaturity of neonatal islets which generate lower ATP and thus a lower secretory response to glucose compared with adult islets (Boschero et al. 1990). Neonatal islets are also known to be better protected than adult islets against oxidative stress due to their more active peroxidase system (Stoppiglia et al. 2002). Indeed, we have found significantly higher expression levels of X-linked inhibitor of apoptosis, which is known to protect against apoptosis, in neonatal compared with adult porcine islets (unpublished observation, Plesner et al. 2005). High glucose has also been shown to have a beneficial effect on neonatal islets by enhancing the $\mathrm{H}_{2} \mathrm{O}_{2}$ scavenger system, a phenomenon not observed in adult islets (Stoppiglia et al. 2002).

Based on in vivo data, which found that exposure to hyperglycemia can increase the $\beta$-cell mass of neonatal porcine islet grafts by $\beta$-cell differentiation from CK7-positive cells, we have now confirmed this observation in vitro (Korbutt et al. 1996, Trivedi et al. 2001, Rayat et al. 2003). Of major significance is the fact that $\beta$-cell apoptosis does not appear to increase in frequency following exposure to high glucose, which is in contrast to the situation with adult human islets. Given the ease by which neonatal porcine islets can be obtained and their enormous growth potential, these insulinproducing cells are a potentially useful source of insulinproducing tissue for clinical transplantation.

\section{Acknowledgements}

The authors thank James Lyon for assistance with the DNA assay. G H is a recipient of an Alberta Heritage Foundation for Medical Research scholarship. G S K is a recipient of a Juvenile Diabetes Research Foundation Career Development Award and is an Alberta Heritage Foundation for Medical Research Senior Scholar.

\section{Funding}

This study was funded by a Canadian Institutes of Health and Research (CIHR) grant, the Alberta Heritage Foundation for Medical Research (AHFMR) and the Juvenile Diabetes Research Foundation (JDRF). The authors have no conflicts of interest that would prejudice the impartiality of this manuscript.

\section{References}

Biarnes M, Montolio M, Nacher V, Raurell M, Soler J \& Montanya E 2002 $\beta$-cell death and mass in syngeically transplanted islets exposed to short- and long-term hyperglycemia. Diabetes 51 66-72.

Bock T, Kyhnel A, Pakkenberg B \& Buschard K 2003 The postnatal growth of the $\beta$-cell mass in pigs. Journal of Endocrinology 179 245-252.

Bonner-Weir S, Deery D, Leahy JL \& Weir GC 1989 Compensatory growth of pancreatic $\beta$-cells in adult rats after short-term glucose infusion. Diabetes 38 49-53.

Boschero AC, Bordin S, Sener A \& Malaisse WJ 1990 D-Glucose and L-leucine metabolism in neonatal and adult cultured rat pancreatic islets. Molecular and Cellular Endocrinology 73 63-71.

Cao LZ, Tang DQ, Horb ME, Li SW \& Yang LJ 2004 High glucose is necessary for complete maturation of $\mathrm{Pdx} 1-\mathrm{VP} 16$-expressing hepatic cells into functional insulin-producing cells. Diabetes 53 3168-3178.

Cardona K, Korbutt GS, Milas Z, Lyon J, Cano J, Jiang W, Bello-Laborn H, Hacquoil B, Strobert E, Gangappa S et al. 2006 Long-term survival of neonatal porcine islets in nonhuman primates by targeting costimulation pathways. Nature Medicine 12 304-306. 
Chen C, Hosokawa H, Bumbalo LM \& Leahy JL 1994 Regulatory effects of glucose on the catalytic activity and cellular content of glucokinase in the pancreatic beta cell. Study using cultured rat islets. Journal of Clinical Investigation 94 1616-1620.

Eizirik DL, Korbutt GS \& Hellerstrom C 1992 Prolonged exposure of human pancreatic islets to high glucose concentrations in vitro impairs the $\beta$-cell function. Journal of Clinical Investigation 90 1263-1268.

Federici M, Hribal M, Perego L, Ranalli M, Caradonna Z, Perego C, Usellini L, Nano R, Bonini P, Bertuzzi F et al. 2001 High glucose causes apoptosis in cultured human pancreatic islets of Langerhans. A potential role for regulation of specific Bcl family genes toward an apoptotic cell death program. Diabetes $\mathbf{5 0}$ 1290-1301.

Gasa R, Fabregat ME \& Gomis R 2000 The role of glucose and its metabolism in the regulation of glucokinase expression in isolated human pancreatic islets. Biochemical and Biophysical Research Communications 268 491-495.

Hostens K, Ling Z, Schravendijk CV \& Pipeleers D 1999 Prolonged exposure of human $\beta$-cells to high glucose increases their release of proinsulin during acute stimulation with glucose or arginine. Journal of Clinical Endocrinology and Metabolism 84 1386-1390.

Kaung HC 1983 Effect of glucose on beta cell proliferation and population size in organ culture of foetal and neonatal rat pancreases. Journal of Embryology Experimental Morphology 74 303-312.

Kim HW, Lee JW, Suh YH, Hong SH, Choi JS, Lim JH, Song JH, Gao B \& Jung MH 2005 Exposure to chronic high glucose induces beta-cell apoptosis through decreased interaction of glucokinase with mitochondria: downregulation of glucokinase in pancreatic beta-cells. Diabetes $\mathbf{5 4}$ 2606-2611.

Kin T, Korbutt GS, Kobayashi T, Dufour JM \& Rajotte RV 2005 Reversal of diabetes in pancreatectomized pigs after transplantation of neonatal porcine islets. Diabetes $\mathbf{5 4}$ 1032-1039.

King DL \& Chick WL 1976 Pancreatic beta cell replication: effects of hexose sugars. Endocrinology 99 1003-1009.

Korbutt GS, Elliot JF, Ao Z, Smith DK, Warnock GL \& Rajotte RV 1996 Large scale isolation, growth, and function of porcine neonatal islet cells. Journal of Clinical Investigation 97 2119-2129.

Korsgren O, Sandler S, Jansson L, Groth CG, Hellerstrom C \& Andersson A 1989 Effects of culture conditions on formation and hormone content of fetal porcine islet like cell clusters. Diabetes 38 209-212.

Korsgren O, Jansson L, Eizirik D \& Andersson A 1991 Functional and morphological differentiation of fetal porcine islet-like cell clusters after transplantation into nude mice. Diabetologia 34 379-386.

Kuhl C, Hornness PJ, Jensen SL \& Lauritsen KB 1980 Gastric inhibitory polypeptide and insulin: response to intraduodenal and intravenous glucose infusions in fetal and neonatal pigs. Endocrinology 107 1446-1450.

Liang Y, Najafi H, Smith RM, Zimmerman EC, Magnuson MA, Tal M \& Matschinsky FM 1992 Concordant glucose induction of glucokinase, glucose usage, and glucose-stimulated insulin release in pancreatic islets maintained in organ culture. Diabetes $\mathbf{4 1} 792-806$.

Ling Z \& Pipeleers DG 1996 Prolonged exposure of human $\beta$ cells to elevated glucose levels results in sustained cellular activation leading to a loss of glucose regulation. Journal of Clinical Investigation 98 2805-2812.

Lukinius A \& Korsgren O 2001 The transplanted fetal endocrine pancreas undergoes an inherent sequential differentiation similar to that in the native pancreas. An ultrastructural study in the pig-to-mouse model. Diabetes $\mathbf{5 0}$ 962-971.

Maga G \& Hubscher U 2003 Proliferating cell nuclear antigen (PCNA): a dancer with many partners. Journal of Cell Science 116 3051-3060.

Marshak S, Leibowitz G, Bertuzzi F, Socci C, Kaiser N, Gross DJ, Cerasi E \& Melloul D 1999 Impaired $\beta$-cell functions induced by chronic exposure of cultured human pancreatic islets to high glucose. Diabetes 48 1230-1236.
Nielsen TB, Yderstraede KB, Schroder HD, Holst JJ, Brusgaard K \& Beck-Nielsen H 2003 Functional and immunohistochemical evaluation of porcine neonatal islet-like cell clusters. Cell Transplant 12 13-25.

Ohgawara H, Kawamura M, Honda M, Karibe S, Iwasaki N, Tasaka Y \& Omori Y 1993 Reversal of glucose insensitivity of pancreatic $\beta$-cells due to prolonged exposure to high glucose in culture: effect of nicotinamide on pancreatic $\beta$-cells. The Tohoku Journal of Experimental Medicine 169 159-166.

Paraskevas S, Maysinger D, Wang R, Duguid WP \& Rosenberg L 2000 Cell loss in isolated human islets occurs by apoptosis. Pancreas 20 270-276.

Plesner A, Liston P, Tan R, Korneluk RG \& Verchere CB 2005 The x-linked inhibitor of apoptosis protein enhances survival of murine islet allografts. Diabetes 54 2533-2540.

Rayat GR, Rajotte RV, Hering BJ, Binette TM \& Korbutt GS 2003 In vitro and in vivo expression of Galalpha-(1,3) Gal on porcine islet cells is age dependent. Journal of Endocrinology 177 127-135.

Sandler S, Welsh M \& Andersson A 1983 Streptozotocin-induced impairment of islet $\mathrm{B}$-cell metabolism and its prevention by a hydroxyl radical scavenger and inhibitors of poly(ADP-ribose) synthetase. Acta Pharmacologica et Toxicologica 53 392-400.

Swenne I, Bone AJ, Howell SJ \& Hellerstrom C 1980 Effects of glucose and amino acids on the biosynthesis of DNA and insulin in fetal rat islets maintained in tissue culture. Diabetes 29 686-692.

Stadlbauer V, Schaffellner S, Iberer F, Lackner C, Liegl B, Zink B, Kniepeiss D \& Tscheliessnigg KH 2003 Occurance of apoptosis during ischemia in porcine pancreas islet cells. International Journal of Artificial Organs $\mathbf{2 6}$ 205-210.

Stoppiglia LF, Nogueira TA, Leite AR, Carneiro EM \& Boschero AC 2002 Protective effect of D-glucose, L-leucine and fetal calf serum against oxidative stress in neonatal pancreatic islets. Biochemica et Biophysica Acto 1588 113-118.

Tang DQ, Cao LZ, Burkhardt BR, Xia CQ, Litherland SA, Atkinson MA \& Yang LJ 2004 In vivo and in vitro characterization of insulin-producing cells obtained from bone marrow. Diabetes 53 1721-1732.

Trivedi N, Hollister-Lock J, Lopez-Avalos MD, O’Neil JJ, Keegan M, Bonner-Weir S \& Weir GC 2001 Increase in $\beta$-cell mass in transplanted porcine neonatal pancreatic cell clusters is due to proliferation of $\beta$-cells and differentiation of duct cells. Endocrinology 142 2115-2122.

Tsuboi T, Ravier MA, Parton LE \& Rutter GA 2006 Sustained exposure to high glucose concentrations modifies glucose signaling and the mechanics of secretory vesicle fusion in primary rat pancreatic $\beta$-cells. Diabetes $\mathbf{5 5}$ 1057-1065.

Tuch BE \& Zheng QL 1993 Chronic hyperglycemia and the human fetal $\beta$ cell. Pancreas 8 719-725.

Yang L, Li S, Hatch H, Ahrens K, Cornelius JG, Petersen BE \& Peck AB 2002 In vitro trans-differentiation of adult hepatic stem cells in pancreatic endocrine hormone-producing cells. PNAS 99 8078-8083.

Yoon KH, Quickel RR, Tarakiewicz K, Ulrich TR, Hollister-LockJ, Trivedi N, Bonner-Weir S \& Weir GC 1999 Differentiation and expansion of beta cell mass in porcine neonatal pancreatic cell clusters transplanted into nude mice. Cell Transplant 8 673-689.

Received 21 March 2006

Received in final form 6 July 2006

Accepted 21 July 2006 